\title{
Pediatric Chronic Rhinosinusitis
}

\author{
Hyun-Jin Cho and Hyo Yeol Kim \\ Department of Otorhinolaryngology-Head and Neck Surgery, Samsung Medical Center, Sungkyunkwan University School of Medicine, \\ Seoul, Korea
}

\section{소아 만성 비부비동염}

\author{
조 현 진·김 효 열 \\ 성균관대학교 의과대학 삼성서울병원 이비인후과학교실
}

Received February 23, 2015

Accepted June 5, 2015

Address for correspondence

Hyo Yeol Kim, MD, PhD

Department of Otorhinolaryngology-

Head and Neck Surgery,

Samsung Medical Center,

Sungkyunkwan University

School of Medicine,

81 Irwon-ro, Gangnam-gu,

Seoul 06351, Korea

Tel +82-2-3410-3579

Fax +82-2-3410-3879

E-mailssiamkhy@gmail.com
Pediatric rhinosinusitis is a common complication of viral upper respiratory infection (URI). According to the previous clinical researches, it has been found that more than 5 percent of children who suffered from URI might be diagnosed with rhinosinusitis. Especially, it might be challenging to clinicians for managing the children with high risk such as, presenting with severe symptoms, younger than 2 years, attending daycare facilities, or who are suspected antimicrobial resistance. Recently, evidence-based guidelines for the diagnosis and treatment of pediatric rhinosinusitis were introduced by the international societies comprising experts of otorhinolaryngology, pediatrics, and infectious disease. In this review, the authors would like to focus on the diagnosis and management of pediatric chronic rhinosinusitis to update and summarize the consensus from these guidelines and recent researches.

Korean J Otorhinolaryngol-Head Neck Surg 2015;58(10):667-75

Key Words Children · Rhinosinusitis - Saline $\cdot$ Surgery.
서 론 해 알아보고자 한다.

소아의 경우 평균 1년에 6 8회 이상 감기에 걸리게 되며 이 중 5 10\%에서 비부비동염으로 이환된다.,2) 이러한 감염은 놀 이방이나 유치원 등 공동생활을 하는 아이들에서 더 흔하며, 최근 여성의 사회진출이 활발해짐에 따라 아이들이 공동생 활을 할 기회가 많아져 점점 그 감염의 기회가 늘고 있어, 이러 한 소아 비부비동염의 병태생리나 진단, 치료에 대한 정확한 지식이 있어야 할 것으로 생각된다. 최근 미국과 유럽에서는 비부비동염의 진단 및 치료를 위한 가이드라인이 각각 발표 되었으나, 소아 비부비동염의 진단 및 치료에는 아직까지도 규명되지 못한 부분들이 많다. ${ }^{3,4}$

저자들은 본 종설에서 이러한 소아 비부비동염, 특히 만성 비부비동염의 진단과 치료에 있어 흔히 지나치기 쉬운 쟁점 들이나 논란의 여지가 있는 부분에 대한 현재까지의 연구 결 과들과 최근의 국제적 가이드라인에서 권장하는 지침에 대

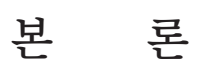

\section{동반 질환 또는 위험 인자들}

만성 비부비동염은 염증으로 인해 부비동의 입구가 막히 게 될 경우 발생하게 된다. 이는 비강 내 분비물의 저류와 환 기장애를 일으켜 점막 내로의 산소의 흡수 및 음압 상태를 야기시킨다. 따라서 비강 또는 비인두에 있는 분비물의 역류 가 부비동 내로 일어나게 되며 바이러스 감염이 있을 경우, 이 또한 섬모운동의 장애를 일으켜 세균의 증식이 일어나기 쉬운 상태가 된다. 이러한 바이러스 감염 외에도 비부비동염 을 일으키기 쉬운 인자들로서는 알레르기비염이나 천식, 아데 노이드 증식, 담배연기 등의 대기오염 물질들, 놀이방 등의 공 동생활, 위식도 역류, 면역기능이상 등이 있으며 비부비동의 구조적 이상은 별 연관이 없는 것으로 알려져 있다.") 


\section{알레르기비염}

알레르기비염은 소아 만성 비부비동염에서 흔히 동반되는 질환이나, 두 질환의 연관성에 관해서는 아직 논란의 여지가 있다. 먼저 과거의 연구들을 살펴보면, 알레르기비염이 비부비 동염과 연관성이 높은 것으로 보고되고 있으며 정상군에서 알레르기비염의 유병률은 15 20\% 정도인 데 반해 비부비동 염 환아의 $80 \%$ 정도에서 알레르기비염에 대한 가족력이 보 고되고 있고, ${ }^{5,6}$ 보고에 따라서는 알레르기와 천식이 반수 이 상에서 관찰되었다는 보고도 있다. ${ }^{7}$ 알레르기 염증에 의해 부 비동염이 발생하는 원인으로서 가장 흔히 생각되는 것은 부 비동입구의 폐쇄이다. 알레르기 염증에 의한 점막부종이 부 비동입구의 폐쇄를 일으키고 이것이 점액배출과 환기를 방해 하여 점액의 저류, 섬모운동의 감소 및 세균의 증식을 일으킨 다는 가설이다. ${ }^{8)}$ 이 외에도 Parsons와 Wald"는 부비동입구의 폐쇄로 인해 발생하는 음압의 상승이 비강 내의 세균들이 부 비동 내로 역류를 야기시킨다고 주장하였으나 아직 이를 뒷 받침하는 데이터는 보고되지 않았다. 하지만 실제로 알레르 기비염 환자의 $75 \%$ 이상에서 알레르겐 투여 후 상악동 점막 의 비후가 관찰된다는 보고도 있었고, ${ }^{10)}$ 정상인의 경우 $33.4 \%$ 에서 CT 상 부비동의 이상이 관찰되나 통년성 알레르기비염 환자의 경우 $67.5 \%$ 에서 부비동의 이상이 관찰된다는 보고도 있어 ${ }^{11}$ 이러한 가설들을 어느 정도 뒷받침한다고 할 수 있다. 하지만 이와는 반대로, Iwens와 Clement ${ }^{12)}$ 는 CT 상 병변의 정도는 아토피 유무와 관련이 없다고 보고하였으며, 최근의 보고에서는 비부비동염 환아와 정상아 사이에 알레르기 검 사결과의 차이가 관찰되지 않았다는 보고도 있어 그 인과관 계는 아직까지도 확실하지 않다.,13)

치료에 있어서도 아직 알레르기비염의 영향은 그다지 관찰 되지 않는다. 알레르기비염이 비부비동염의 원인인자라고 하 면 치료에 있어서도 항히스타민의 사용이 비부비동염의 치료 에 효과가 있어야 하지만 아직까지 이에 대한 명확한 자료는 없다. 오히려 급성 비부비동염에서의 placebo controlled trial 에서 1 세대 항히스타민의 사용이 대조군과 차이가 없다는 보 고도 있다. ${ }^{14)}$ 하지만 이 실험에서는 항콜린 작용이 강한 1 세대 항히스타민을 사용하였으며, 이후 생산된 2세대 항히스타민 의 경우 항콜린 작용이 적어 알레르기비염이 동반된 비부비동 염의 경우 사용을 생각해볼 수도 있겠다.

\section{천 식}

성인에서 보고된 바와 같이 ${ }^{15-17)}$ 소아에서도 만성 비부비동 염에 천식이 동반된 경우가 많다. 비록 오래된 연구이기는 하 지만 천식과 만성 비부비동염이 동반된 환자에서 부비동염 에 대한 약물 및 수술적 치료를 시행할 경우 $80 \%$ 의 환아에서
천식 치료를 줄일 수 있으며, 이 환아들에서 비부비동염이 재 발한 경우 천식도 같이 재발하였다는 보고도 있다. ${ }^{18)}$

\section{흡 연}

중이염과 마찬가지로 흡연 역시 급, 만성 비부비동염의 발 생에 중요한 역할을 한다. 흡연은 비점막의 만성적인 염증과 염증 매개물질의 증가를 일으키며 비강 및 부비동 점막의 부 종을 일으켜 만성 비부비동염을 야기시키게 된다. 소아의 경우 직접적인 흡연보다 가정에서의 간접적인 흡연이 문제가 되는 데 간접흡연 역시 섬모운동을 방해해 비부비동염을 야기시 키며, 간접흡연이 소아에서의 비강면적을 감소시킨다는 보고 도 있으며,1,19) 가정에서의 간접흡연은 호흡기 감염의 위험성 을 높이고(OR 1.19), 엄마가 흡연을 하거나 임신 중 흡연을 한 경우에는 그 위험성이 더욱 높아진다. ${ }^{20)}$ 또한 소아 부비동 내시 경수술의 경우 간접흡연이 수술의 경과를 유의하게 악화시킨 다는 보고들이 나오고 있어 이에 대한 주의가 필요하다. 21,22)

\section{공동생활}

또 다른 비부비동염의 원인인자는 놀이방 등의 공동체 생활 이다. 5 인 이상의 놀이방에서 다니는 소아의 경우 upper respiratory infection 및 비부비동염, 중이염의 위험성이 증가하 며, ${ }^{23}$ 항생제 치료에 대한 내성률의 증가도 보고되고 있어 최근 의 미 소아과학회(American Academy of Pediatrics, AAP)의 가이드라인에서는 이러한 환아의 경우 고용량 항생제를 권장 하고 있다. ${ }^{24)}$

\section{위식도 역류}

소아에서 위식도 역류와 비부비동염과의 관계에 대해서는 아직 논란의 여지가 많지만 적어도 일부에서의 가능성은 인 정되고 있다. Suskind 등 25$)$ 은 위식도 역류로 치료를 받은 82 명의 환아 중 $17 \%$ 에서 상기도 이상을 보고하였으며, Bothwell 등 $^{26}$ 과 Phipps 등 ${ }^{27)}$ 은 만성 비부비동염 환자군에서 위식도역 류의 발병률이 높은 것을 보고하였다. 또한 항생제 치료에 반 응하지 않는 만성 비부비동염 환자에서 위식도 역류에 대한 치료를 시행함으로써 대상군의 90\%에서 비부비동염에 대한 수술을 피할 수 있었다는 보고도 있다. ${ }^{26}$ 최근에는 위식도 역 류가 비부비동염에 끼치는 영향으로서 위산에 의한 직접적인 자극, 미주신경매개반사, H. pylori의 역할 등을 제시하였으 나 아직까지 이에 대한 연구는 evidence가 부족한 실정이다.

\section{원인 및 병태생리}

소아 만성 비부비동염의 정확한 유병률은 알려져 있지는 않지만, 나이에 따른 유병률의 차이는 있는 것으로 알려져 
있으며, 나이가 소아 만성 비부비동염의 가장 중요한 단일 위 험요소로 알려져 있다. 실제, 만성 비부비동염이 의심되는 환 자의 63\%는 CT의 이상 소견이 관찰되었고, 이는 2 6세 환자 군의 $73 \%, 6 \sim 10$ 세 환자군의 $74 \%, 10$ 세 이상 환자군의 $38 \%$ 에 해당한다는 보고가 있다. ${ }^{7)}$

\section{미생물학적 요소}

소아 만성 비부비동염의 원인균은 alpha hemolytic Streptococci, Staphylococcus aureus 가 가장 흔하고, S. pneumoniae, H. influenzae, M. catarrhalis도 비교적 흔하다고 알려 져 있다. 또한 만성으로 진행하면서 혐기성 균주도 상대적으 로 증가한다. ${ }^{28)}$

Biofilm 또한 소아 만성 비부비동염의 원인으로 거론되고 있는데, 이는 구조적, 유전적 변화와 함께 균주들 간의 상호 작용, 세포외 기질의 다양성 등을 특징으로 하여 항생제 내 성의 발현에 원인으로 언급되고 있다. 하지만, 소아의 경우는 추가적인 연구를 통한 근거가 필요한 단계이다.

\section{만성 비부비동염에 있어서 아데노이드의 역할}

아데노이드는 해부학적 구조 상 비강 및 부비동에 인접해 있으며, 과거부터 약물에 반응하지 않는 만성 비부비동염의 1 차적 치료로서 이용되어 왔다. 아데노이드가 만성 비부비동 염에 영향을 미치는 기전은 크게 두 가지 경우로 생각하고 있으며 그중 한 가지는 아데노이드가 박테리아의 저장소 역 할을 한다는 것이다. 실제로 여러 연구에서 만성 비부비동염 환아에서 아데노이드의 세균배양 결과 및 molecular typing 이 중비도의 그것과 일치한다고 보고 되었으며, ${ }^{29,30)}$ 이러한 만 성 비부비동염 환아(88 99\%)에서는 대조군보다(0 6.5\%) 훨 씬 높은 빈도로 아데노이드의 바이오필름 형성이 관찰되었 다. 그리고 만성 비부비동염이 동반된 환아의 아데노이드에 서 정상인에 비해 $\operatorname{IgA}$ 의 분비가 적다는 보고도 있다. ${ }^{31}$

그뿐 아니라, IgA 발현 빈도와 tissue-remodeling cytokines(TGF- $\beta 1, \mathrm{MMP}, \mathrm{TIMP}-1)$ 의 발현 빈도가 비부비동염 의 유무에 따라 다르게 나타났다는 보고들도 있어 아데노이 드가 세균학적, 면역학적으로 소아 만성 비부비동염에 관여 하고 있음을 알 수 있다. 하지만, 아데노이드의 크기와 비부 비동염의 심한 정도는 유의한 차이가 없어, ${ }^{32)}$ 결론적으로 아 데노이드는 해부학적 요인보다는 세균학적, 면역학적으로 소 아 만성 비부비동염에 관여하고 있음을 알 수 있다.

\section{진 단}

소아 비부비동염의 진단은 몇 가지 면에서 어른에 비해 어려 운 점이 있다. 먼저 소아의 경우 어른과 달리 본인의 증상을 명
확하게 설명하지 못하기 때문에 기침이나 캑캑거림, 두통 등 의 비특이적인 증상으로 표현되는 경우가 많고, 따라서 알레 르기비염이나 감기, 편도 및 아데노이드 비후 등의 다른 이비 인후과 질환과 혼동될 위험성이 있다. 따라서 소아 만성 비부 비동염의 진단을 위해서는 기본적으로 가족력과 과거병력, 환 아의 증상에 대한 자세한 질문을 포함한 병력청취와 세밀한 신체검사가 필요하다. 특히, 비강에 대한 검사는 내시경(협조 가 힘든 경우는 전비경 및 이경을 사용)을 통해 중비도, 하비 갑개, 전반적인 점막의 상태를 확인하는 것이 중요하고, 구강 에 대한 검사를 통해 농성 분비물의 유무, 편도의 비대, 후인 두 점막의 상태를 확인해야 한다.

또한 소아 만성 비부비동염 환아에서는 알레르기비염이 동반된 경우가 많으므로 이에 대한 단자검사나 혈액검사를 고려하여야 하며, 자주 재발하거나, 약물치료에 잘 반응하지 않고 세균배양검사에서 흔하지 않은 균이 관찰될 경우에는 필요에 따라 면역결핍에 대한 검사를 시행할 수도 있다. 농성 분비물이 심하거나 약물치료에 잘 반응을 하지 않는 경우 세 균배양검사를 추가로 시행하는 것을 고려해야 한다. ${ }^{4)}$ 영상의 학 검사는 X-ray 검사보다는 CT를 확인하는 것이 진단에 도 움이 된다고 알려져 있다. 특히, 수술적 치료를 고려하고 있을 때는 CT를 확인하는 것이 필수적이며, 만성 비부비동염에 의 한 합병증이 의심될 때는 MRI를 통한 병변의 확인이 중요하다.

\section{방사선학적 검사가 진단에 필요한가?}

만성 비부비동염의 진단은 대체로 임상적으로 이루어질 수 있으나, 약물에 반응하지 않고 재발이 잦은 만성 비부비동염 에서는 방사선학적인 검사가 필요하며, 이때 가장 적절한 검사 (imaging modality of choice)는 CT이다. ${ }^{4,33)}$

과거 수십 년간 비부비동염의 진단에 사용되어 온 단순방사 선 검사는, CT에 비해 가격이 낮고 유아의 경우 검사 전 진정 제 사용이 필요하지 않은 면에서 장점이 있다. 하지만 검사의 정확도는 비교적 낮은 편이며, 부비동 내의 전체적인 혼탁(total opacification) 및 공기 액체층(air-fluid level)을 기준으 로 할 경우 민감도는 $54 \%$, 특이도는 $92 \%$ 였으며, CT와 동시 에 단순방사선 검사를 시행한 연구에서는 $74 \%$ 에서 두 검사 사이에 차이가 발생하였다고 보고하여 ${ }^{34)}$ 검사에 대한 판독 시 주의를 요한다.

현재까지는 급성 비부비동염의 진단에 있어서 방사선학적 검사는 불필요하다는 것이 대부분의 의견이다. 2001년에 미 소아과학회(AAP)에서 발표한 가이드라인에서는 6세 이하의 소아의 경우는 비부비동염의 진단을 위해 방사선검사를 사용 할 필요가 없으며 6세 이상에서도 선택적으로 사용할 것을 권 고하였다. ${ }^{24)}$ 이에 대한 근거로서 소아의 경우 실제로 6세 이하 
의 경우 비부비동 증상만으로도 방사선검사 이상의 $88 \%$ 를 예측할 수 있다고 보고되었으면) 6 세 이상의 경우에도 $70 \%$ 를 예측할 수 있다고 보고되었다. ${ }^{24)}$ 또한 미국 방사선과학회

(American College of Radiology)나 Sinus and Allergy Health Partnership의 가이드라인에서도 합병증이 없는 단순 비부 비동염에서 방사선검사는 필요하지 않다고 권고하였다. ${ }^{27,34)}$ 따라서 급성 비부비동염의 경우에는 방사선학적 검사는 대 부분 필요하지 않으며, 이후 약물치료에 반응하지 않거나 수 술을 필요로 하는 경우 등에서 선택적으로 사용하는 것이 좋 으리라 생각된다.

\section{균동정을 위한 상악동 천자가 꼭 필요한가?}

약물치료에 반응을 하지 않는 경우 균배양검사를 시행하 게 된다. 과거에는 이런 경우 상악동을 천자하여 균동정을 시 행하였으나, 여러 논문에서 중비도에서의 균동정이 상악동 천 자에서의 결과와 높은 수준으로 일치한다고 보고하여, 통증 에 취약한 소아에서 상악동 천자를 꼭 시행할 필요는 없다고 생각된다. ${ }^{36,37)}$ 또한 최근에 면봉을 이용한 단순 swab culture (66\%)보다는 suction aspiration culture(87\%)가 상악동 천자 의 결과와 일치도가 높은 것으로 보고되었으나, 통증을 야기 할 수 있으므로 나이가 많은 소아에서 사용하는 것이 좋다고 생각된다. ${ }^{38)}$

\section{내과적 치료}

소아 만성 비부비동염에 대한 내과적 치료는 아직까지 consensus가 확립되어 있지 않다. 2012년에 발간된 European position paper on rhiniosinusitis and nsal polyps에서는 식 염수 세척과 비강 스테로이드 제제가 효과가 있다고 보고하 였으며, 단기 항생제 요법은 효과가 없는 것으로 보고하였다. 다만 저용량 장기간 마크로라이드 치료(low dose long term macrolide, LDLT)에 대한 가능성은 열어두었다(Table 1). ${ }^{4}$

\section{항생제}

소아 만성 비부비동염의 치료에 있어 항생제 사용에 대해
서는 확립된 근거가 없다. 만성 비부비동염에 있어서는 항생 제 사용군이 기타 생리식염수 사용군이나 배액 및 세척(drainage and irrigation)군에 비하여 장기적으로 추적 관찰하였을 때, 치료 성공의 측면에서 유의한 결과를 도출해 내지 못했으 며, ${ }^{39)}$ 이후 진행된 연구에서도 위약군에 비해 의미 있는 결과 를 보이지 못했다. ${ }^{40)}$

하지만 소아 만성 비부비동염 환자의 많은 수가 잦은 급성 악화에 의한 발열, 화농성 비루, 안면통 등의 심한 증상을 이 유로 치료를 받게 되며, 급성 비부비동염이 병발하는 경우는 대증적 치료 이외에도 일차적으로 항생제 치료가 요구된다. 일반적으로 이러한 항생제의 사용 빈도가 지나치게 높은 경우 나 일반적인 항생제 치료에 반응이 없는 경우 적극적인 치료 혹은 수술적 치료까지도 고려하게 된다.

또한, 실제적으로는 소아 만성 비부비동염 환자에서 급성 비부비동염 환자에서 보다 더 장기간(약 3 6주)의 항생제를 사용하고 있는 경향을 보이고 있다.41-43) 일전에 대한비과학회 학술심포지엄에서 실시한 실시간 설문조사에서도 약 $70 \%$ 정도의 의사들이 수술 전 2개월 이상의 항생제를 사용하는 것 으로 보고하여 상당히 장기간 항생제 사용이 이루어지는 것 을 알 수 있었다. 여기서 주의해야 할 것은 광범위 항생제보 다는 지역의 호발 균주와 항생제 내성을 고려한 최소한의 항 생제 사용이 우선되어야 한다는 것이다. 지금까지의 데이터는 소아 만성 비부비동염에서의 단기간 항생제 사용을 정당화할 근거는 없으며, $\mathrm{LDLT}$ 의 사용은 비록 그 근거는 낮지만 사용 해볼 수 있을 것으로 생각된다.

항생제의 선택에 있어 우선 생각할 것이 항생제에 대한 내성 기전인데 미국의 경우에도 H. influenzae의 $50 \%$ 와 $100 \%$ 의 M. catarrhalis에서 beta-lactamase가 관찰되며 이 두 세균의 내성기전은 이 beta-lactamase에 의한다. ${ }^{44,45}$ 따라서 amoxicillin-clavulanate를 사용할 경우 이 두 세균에 대한 치료 성공률은 거의 $100 \%$ 에 달할 수 있다고 보고되었다. ${ }^{46)}$ 반면 S. pneumoniae의 내성기전은 beta-lactamase의 생산이 아니 라 penicillin binding protein의 변형에 의한 것으로서 clavulanate의 작용보다는 고용량의 amoxicillin에 반응을 하므

Table 1. Evidence and recommendations of medical treatment for children with chronic rhinosinusitis

\begin{tabular}{llcc}
\multicolumn{1}{c}{ Treatment } & Evidence level & Grade of recommendation & Relevance \\
\hline Nasal saline irrigation & la & A & Yes \\
Therapy for GERD & III & C & No \\
Topical steroid & IV & D & Yes \\
Oral antibiotics (short term, $<4$ weeks) & $\mathrm{lb}(-)^{*}$ & $\mathrm{~A}(-)^{\dagger}$ & No \\
Oral antibiotics (long term) & No data & D & Unclear \\
Intravenous antibiotics & $\mathrm{III}(-)^{\ddagger}$ & $\mathrm{C}(-) \S$ & No \\
\hline
\end{tabular}

Evidence level and grade of recommendation refer to the EPOS guideline 2012. *level lb study with a negative outcome, tgrade A recommendation not to use, flevel III study with a negative outcome, sgrade C recommendation not to use. GERD: gastro-esophageal reflux disease 
로 고용량의 amoxicillin(amoxicillin component 80 90 mg/ $\mathrm{kg}$ and clavulanate $6.4 \mathrm{mg} / \mathrm{kg}$ in 2 divided doses)을 사용 할 수 있다. 하지만 내성균 중 일부는 고도 내성을 보여 고용 량 amoxicillin에도 반응하지 않는다..$^{24,27,47,48)}$ 특히 이와 같은 고용량 amoxicillin 요법은 2세 미만의 환아, 증상이 심할 때, 보육시설에 다니는 경우 또는 최근의 일반적 항생제 치료에 반응이 만족스럽지 않은 경우에 권장된다. ${ }^{49)}$

2005년 국내에서 발간된 논문에 따르면 pneumococcus에 대한 항생제 감수성이 amoxicillin-clavulanate의 경우에는 $32.5 \%$ 였으며, 반면 cefditoren이나 ceftriaxone의 경우 각각 $97.4 \%, 100 \%$ 에 달해 amoxicillin-clavulanate 초치료에 효과 가 없을 경우 고용량의 항생제를 사용하거나 상기 cephalosporin계로 바꾸는 것도 생각해볼 만하다. 고용량의 amoxicillinclavulanate를 사용시에도 위장관계 합병증의 발생률은 저용 량에서와 동일하다. ${ }^{50)}$

약물치료를 최대한 하였는데도 반응이 없는 만성 비부비동 염의 경우 항생제 정맥 요법이 시행되기도 하는데, 아데노이드 절제술, 상악동 세척(irrigation) 등과 함께 사용되었을 때, $89 \%$ 이상의 높은 장기 치료율이 보고된 바 있다. ${ }^{51,52)}$ 하지만 아직 까지 항생제 정맥 요법 단독의 효과는 확인된 바 없으므로 이 에 대해서는 주의하여야 하겠다.

\section{스테로이드}

아직까지 소아에 있어서 비강 내 스테로이드 제제의 효과를 입증한 무작위 연구는 없지만 국소스테로이드 제제의 사용시 부비동염을 호전시킬 뿐만 아니라 수술의 필요성을 낮춘다 는 보고가 있다. ${ }^{53-55)}$ 또한 성인에서 이미 그 효과가 증명되었고 소아에서의 안전성이 증명된 점을 고려해보면 소아 만성 비 부비동염에서도 1 차 치료로 사용될 수 있다고 생각된다. 또한 최근 시행된 무작위 연구에서 경구용 스테로이드를 항생제와
더불어 사용한 군에서 그렇지 못한 군에 비해 기침, 코막힘, 후비루 등의 증상점수와 $\mathrm{CT}$ 중증도가 유의하게 좋아진 것을 보고하여, ${ }^{56)}$ 소아에서 스테로이드의 효과를 예상해볼 수 있 겠다.

\section{식염수 세척}

생리식염수를 이용한 세척 및 혈관수축제는 만성 비부비동 염의 호전에 어느 정도 역할을 할 것으로 생각되지만, 이에 대 한 유의한 결과를 보여준 비교 연구는 없다. 또한 식염수 세 척은 성인 비부비동염에서는 임상적으로 많이 사용되어 왔 지만 소아는 상대적으로 시행하기 힘들 것이라는 우려가 많 다. 하지만 생리식염수 세척은 특별한 부작용을 일으키지 않 으며 만성 비부비동염의 증상 호전의 측면에서 이득이 있다. 최근 전체 환아의 $70 \%$ 이상에서 식염수 세척을 잘 시행하였 다는 보고도 있으며, ${ }^{57)}$ 본 교실에서도 이에 대해 최근 해외 학술지에 보고한 바 있다. ${ }^{58)}$ 저자는 2007년 1월부터 2010년 6 월까지 치료받은 77 명의 13 세 이하의 증상이 심하여 항생 제 및 비강 내 스테로이드제 치료에도 호전되지 않아, 수술 여 부를 판단하기 위해 $\mathrm{CT}$ 를 시행한 소아 환자를 대상으로 후 향적 환자-대조군 연구를 시행하였다. 순응도는 나이가 많 은 환아가 더 높을 것이라는 예상과 달리 6 8세의 환아에서 비교적 높은 순응도를 보였으며, $64 \%$ 의 환아에서 성공적으 로 지속적인 식염수 세척을 시행할 수 있었다. 또한 임상적 측 면으로 보았을 때, 치료 순응도가 높은 군에서 통계적으로 유의한 주관적, 객관적 호전 소견을 보였으며, 결과적으로 아 데노이드 절제술 및 기능적 내시경 부비동 수술을 시행받은 환자들 또한 치료 순응도가 나쁜 군에서 많은 것을 확인할 수 있었다(Fig. 1). 본 연구 결과로 미루어 보아, 소아 만성 비부 비동염 환자에서 생리식염수 세척은 항생제나 비강 내 스테 로이드제와 함께 사용할 수 있는 효과적인 방법으로 생각된

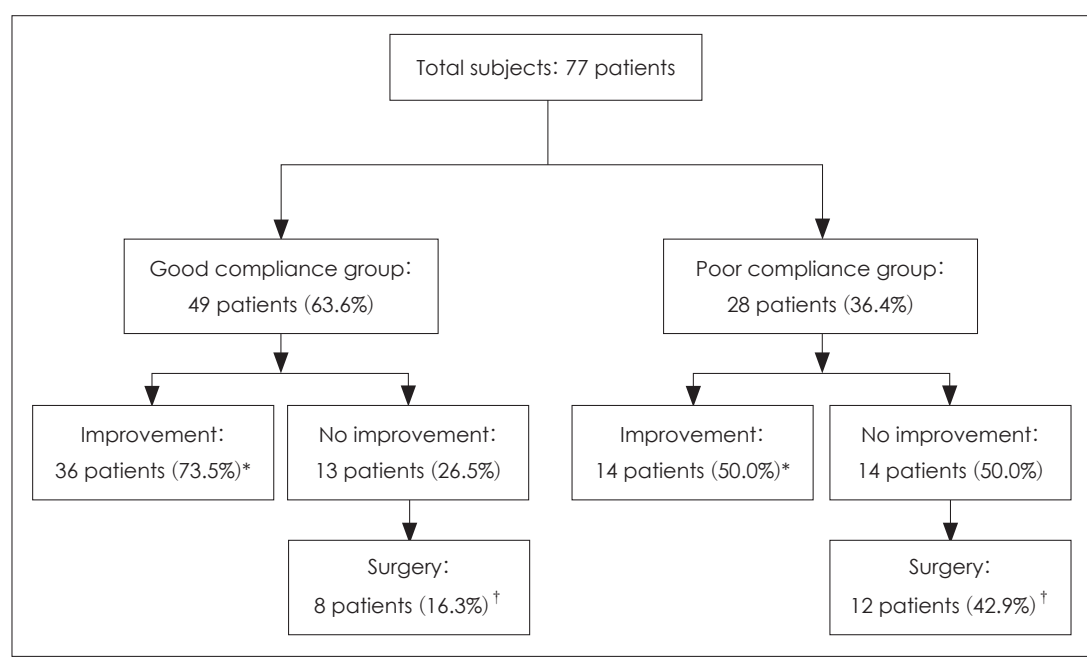

Fig. 1. Treatment outcomes according to compliance with nasal saline irrigation. Treatment outcomes including subjective and endoscopic improvements and the rate of surgery were significantly different between groups $\left({ }^{*} p=0.048,{ }^{\dagger} p=0.019\right)$. 
다. 2007년 발표된 Cochrane review에서도 식염수 세척이 단 독, 또는 다른 치료와 함께 사용하였을 경우 만성 비부비동염 의 치료에 효과적이라고 보고하였다.

\section{기타 제제}

항히스타민제와 항류코트리엔제 또한 알레르기비염의 치료 에서는 효과가 밝혀져 있지만, 만성 비부비동염에 대한 효과 는 밝혀진 바 없으므로 알레르기비염이 동반된 경우에 한해 사용하는 것이 추천된다.

\section{외과적 치료-What to do and when do we operate?}

\section{수술의 대상 및 시기}

소아 비부비동염의 치료에 있어 가장 어려운 결정은 어떤 환 자군을 언제 수술하느냐 하는 것이다. 지금까지 많은 의사들 이 사용하는 기준은 안와 합병증 등 합병증이 있는 경우를 제외하고는 최대한의 내과적 치료에도 불구하고 증상의 호 전이 없는 경우에 수술을 결정하게 된다. 그러면 과연 이 최대 한의 내과적 치료는 무엇을 말하는 것인가? 이는 상당히 주관 적인 용어로서 아직까지 이에 대한 객관적인 결과들은 없는 실정이나 여러 연구 결과들을 미루어볼 때 항생제 치료와 비 강 스테로이드 제제를 기본으로 ${ }^{1)}$ 알레르기 및 위식도 역류가 있는 경우 이에 대한 치료를 모두 시행하는 것을 의미한다고 생각된다. 그러면 이러한 최대한의 내과적 치료의 기간은 얼 마나 될 것인가? 아쉽게도 이에 대해서도 아직까지 공통된 의 견은 없는 실정이며 저자들에 따라 경험적으로 3 6주 정도를 권장하고 있다. ${ }^{41-43)}$

한 가지 재미있는 연구는 2003년 Lieu 등 ${ }^{59)}$ 은 소아 비부비 동염 환자를 증상의 심한 정도에 따라 4단계로 나누어 부비 동 내시경수술과 내과적 치료의 성공률을 비교하였는데 2,3 단계 증상을 가진 사람들에서는 수술의 호전율이 내과적 치 료에 비해 훨씬 높았는데(각각 $79 \%$ vs. $54 \%, 68 \%$ vs. $42 \%$ ) 증상이 가장 경한 1 단계와 가장 심한 4단계에서는 오히려 약 물치료 후 호전율이 수술에 비해 더 높았다(각각 $38 \%$ vs. 56\%, $43 \%$ vs. $67 \%$ ). 또한 저자가 발표한 연구에서도 병변의 중증 도가 수술 후 예후에 중대한 영향을 미쳤다. ${ }^{21)}$ 이와 같은 결과 로 미루어 볼 때 수술이 필요하다고 생각되는 경우에는 너무 미루지 않고 조기에 시행하는 것이 필요하다고 생각된다.

\section{수술의 선택}

일단 수술이 결정되면 어떤 수술을 시행할 것인가 하는 것이 다음 과제가 된다. 보통 선택할 수 있는 옵션으로는 아데노이 드 절제술과 부비동 내시경수술이 있으며 각각의 장단점이
있으나 보통 수술의 간단함과 상대적으로 좋은 효과, 그리고 안면성장에 문제가 없을 것이라는 이유로 아데노이드 절제 술을 먼저 시행하는 경우가 많으며, 2005년에 미국 소아이비 인후과의사를 대상으로 한 설문조사에서도 만성 비부비동염 에 수술적 치료에 있어 아데노이드 절제술을 1 차적으로 시행 하는 의사가 $81 \%$ 였으며, 부비동 내시경수술과 동시에 시행하 는 경우가 $13 \%$ 로 보고되었다. ${ }^{60)}$ 올해 대한비과학회 심포지엄 에서 시행한 실시간 설문조사에서는 전체 응답자의 $56 \%$ 에 서 만성 비부비동염에 있어서 아데노이드 절제술을 1 차적인 수술로 시행한다고 응답하여, 우리나라에서도 과거에 비해 부비동 내시경수술을 함께 시행하는 경우가 늘어나고 있는 것 을 알 수 있다.

만성 비부비동염에 있어서 아데노이드의 역할이 확실하게 밝혀지지는 않았지만 보통 두 가지로 요약된다. 그 첫째는 아 데노이드가 만성 비부비동염에 있어서 병원균의 저장소 역할 을 한다는 것이다. 여러 연구들에 따르면 아데노이드에서 채 취한 세균집락수가 비부비동 증상점수와 연관이 있고 $89 \%$ 에 서 중비도와 아데노이드 균배양검사의 molecular typing이 일치하며 아데노이드 제거 후 비강 내 정상 상재균이 증가하고 병원균이 감소한다고 보고되었다. ${ }^{29,61,62)}$ 다음으로 비대한 아 데노이드가 비강 분비물이 뒤로 넘어가는 것을 막고 정체시 킴으로써 또는 아데노이드가 비인두를 막을 정도로 크지는 않 더라도 계속된 염증으로 편평상피화가 일어남으로써 점액섬 모운동이 저하되어 비부비동염이 발생할 수 있다는 것이다. ${ }^{63)}$

소아 만성 비부비동염의 수술적 치료에 있어 아데노이드 절 제술의 효과는 meta-analysis를 통해 잘 밝혀져 있다. 평균 5.8 세 환자를 대상으로 한 9개의 연구를 분석한 결과 $69.3 \%$ 의 환자에서 호전을 보였다. ${ }^{64)}$ 또한 Ramadan과 Tiu, ${ }^{65)}$ Ramadan과 $\operatorname{Cost}^{66)}$ 는 7세 이하이거나 천식이 동반된 환아의 경우 아데노이드 절제술의 효과가 떨어지며, 이차적으로 부비동 내 시경수술이 필요한 경우가 많다고 보고하였다. 또한 아데노 이드 절제술과 함께 중비도를 통한 부비동 세척을 시행하였 을 때, 아데노이드 절제술을 단독으로 시행한 환자군에 비해 높은 호전율을 보였다는 연구 결과도 보고된 바 있다(success rate $88 \%$ vs. $61 \%)^{66)}$

따라서 만성 비부비동염의 수술적 치료에 있어 수술의 간단 함이나 효과 등을 생각하면 아데노이드 절제술을 1 차적으로 생각하여야 하는 것은 당연하다. ${ }^{1,23)}$ 또한 수술 시 중비도나 상 악동에서 균배양검사를 시행함으로써 이후 항생제 치료 시 도움이 될 수 있다.

그렇다면 만성 비부비동염의 치료에 있어 내시경수술의 역 할은 무엇이며 수술을 필요로 하는 모든 만성 비부비동염 환 아에서 아데노이드 절제술을 먼저 시행하여야 할까? 아데노 
이드의 사이즈가 크고 수술을 필요로 하는 어린 소아의 경우 에는 아데노이드 절제술을 먼저 시행하는 것에 많은 사람들 이 동의하지만 나이가 들어가면서 아데노이드 크기가 작은 소아에서도 아데노이드 절제술만을 시행하느냐 하는 데에는 아직 논란의 여지가 많은 실정이다. 이전의 논문들에서는 아 데노이드의 크기에 관계없이 아데노이드 절제술을 1차적으 로 시행한다고 보고하였다. ${ }^{43,62,67)}$ 하지만 Ramadan ${ }^{68}$ 은 천식 이 있거나 나이가 많은 경우, CT score가 높은 경우에는 아데 노이드 절제술만으로는 만족스러운 결과를 얻지 못한다고 보고하였으며 부비동 내시경수술을 함께 시행할 것을 권고 하였다.

기능적 부비동 내시경수술은 최근 meta-analysis에서 소아 만성 비부비동염 환자에서 $88 \%$ 의 성공률과 낮은 합병증 빈 도를 보고하여 효과적인 수술적 치료의 방법으로 생각된다. ${ }^{69}$ 하지만 앞에서도 보다시피 많은 의사들이 아직까지 아데노 이드 절제술을 1 차적으로 시행하는 경우가 많으며, 여기에는 많은 이유가 있지만 무엇보다도 소아에서 부비동 내시경수술 을 시행할 경우 가장 먼저 대두되는 문제가 수술이 안면성장 에 영향을 미칠 수 있으리라는 우려 때문이다. 이는 1990년 대 중반에 발표된 두 편의 동물실험에 기초를 두고 있으며 이 논문들에 따르면 전사골동제거술과 같은 최소한의 술식 조차도 안면골의 변형을 야기시킨다고 보고하였다. ${ }^{70,71)}$ 하지 만 이후 발간된 임상논문들에서는 이와 반대의 결과들을 보 고하였으며 내시경수술 후 성형외과전문의의 검진결과 수술 이 안면성장을 이상을 일으키지 않았다고 보고하여, ${ }^{72,73)}$ 내시 경수술로 인한 안면성장의 장애는 없으리라 생각된다. 하지만 소아의 경우 어른보다 비강 사이즈가 작아 부비동 내시경수 술을 시행하기가 불리한 점이 있다. 또한 많은 보고들에서 성 인과 비슷한 정도의 유착 등의 합병증 발생률을 보고하지만 이는 이 분야에서 많은 경험을 쌓은 의사들이며 처음 소아 부 비동 내시경수술을 시행하는 의사의 경우 성인보다 많은 어려 움을 겪게 된다. ${ }^{74)}$ 하지만 이는 경험을 쌓으면서 해결될 수 있 는 문제이며 또한 최근 크기가 작은 cutting forceps 등의 발 달로 인해 이전에 비해 수술이 횔씬 편리해졌다. 또한 실제로 수술 후 주합병증의 빈도도 $1 \%$ 이하로 보고되어 성인에서의 부비동 내시경수술에 비해 위험한 편은 아니다. ${ }^{69)}$

최근에는 balloon sinuplasty가 소아 만성 비부비동염에 대 한 수술적 치료의 새로운 선택 사항으로 사용될 수 있을지에 대한 연구들이 진행되고 있다. Balloon sinuplasty는 2006년 미국 식품의약기구(Food and Drug Administration)에서 승 인되어 성인을 대상으로 한 연구에서 안전성 및 유효성을 검 증한 이후에 소아에 사용되기 시작하였다. 이후 연구 결과에 따르면 balloon sinuplasty를 이용한 상악동 확장 및 세척술
이 아데노이드 절제술 단독 시행군보다 의미 있는 호전 소견 을 보였으나 이것이 irrigation에 대한 효과인지에 대해서는 논란의 여지가 있다. ${ }^{75)}$

\section{결 론}

결론적으로 소아 만성 비부비동염의 경우 최대한의 약물 치료를 시행하였는데도 호전이 없을 때, 수술적 접근을 고려 할 수 있으며, 병변이 심하지 않을 경우에는 아데노이드 절제 술과 부비동 세척이 우선적으로 고려되어야 하겠다. 그럼에 도 불구하고 증상의 호전이 없거나 재발한 경우, 병변이 심하 거나 천식 등 점막의 염증성 질환을 동반할 수 있는 질환이 있는 경우에는 기능적 부비동 내시경수술을 선택하는 것이 유리하리라 생각된다.

\section{REFERENCES}

1) Goldsmith AJ, Rosenfeld RM. Treatment of pediatric sinusitis. Pediatr Clin North Am 2003;50(2):413-26.

2) Herrmann BW, Forsen JW Jr. Simultaneous intracranial and orbital complications of acute rhinosinusitis in children. Int J Pediatr Otorhinolaryngol 2004;68(5):619-25.

3) Chow AW, Benninger MS, Brook I, Brozek JL, Goldstein EJ, Hicks LA, et al. IDSA clinical practice guideline for acute bacterial rhinosinusitis in children and adults. Clin Infect Dis 2012;54(8):e72112.

4) Fokkens WJ, Lund VJ, Mullol J, Bachert C, Alobid I, Baroody F, et al. EPOS 2012: European position paper on rhinosinusitis and nasal polyps 2012. A summary for otorhinolaryngologists. Rhinology 2012;50(1):1-12.

5) Shapiro GG, Rachelefsky GS. Introduction and definition of sinusitis. J Allergy Clin Immunol 1992;90(3 Pt 2):417-8.

6) Shapiro GG, Virant FS, Furukawa CT, Pierson WE, Bierman CW. Immunologic defects in patients with refractory sinusitis. Pediatrics 1991;87(3):311-6.

7) Nguyen KL, Corbett ML, Garcia DP, Eberly SM, Massey EN, Le HT, et al. Chronic sinusitis among pediatric patients with chronic respiratory complaints. J Allergy Clin Immunol 1993;92(6):824-30.

8) Silviu-Dan F. Pediatric chronic rhinosinusitis: the old, the new, and the reasonable. Pediatr Ann 2011;40(4):213-20.

9) Parsons DS, Wald ER. Otitis media and sinusitis: similar diseases. Otolaryngol Clin North Am 1996;29(1):11-25.

10) Pelikan $Z$. The role of allergy in sinus disease. Children and adults. Clin Rev Allergy Immunol 1998;16(1-2):55-156.

11) Berrettini S, Carabelli A, Sellari-Franceschini S, Bruschini L, Abruzzese A, Quartieri F, et al. Perennial allergic rhinitis and chronic sinusitis: correlation with rhinologic risk factors. Allergy 1999;54(3):242-8.

12) Iwens $P$, Clement PA. Sinusitis in allergic patients. Rhinology 1994; 32(2):65-7.

13) Leo G, Piacentini E, Incorvaia C, Consonni D, Frati F. Chronic rhinosinusitis and allergy. Pediatr Allergy Immunol 2007;18 Suppl 18:19-21.

14) McCormick DP, John SD, Swischuk LE, Uchida T. A double-blind, placebo-controlled trial of decongestant-antihistamine for the treatment of sinusitis in children. Clin Pediatr (Phila) 1996;35(9):45760.

15) Dhong HJ, Kim HY, Cho DY. Histopathologic characteristics of chronic sinusitis with bronchial asthma. Acta Otolaryngol 2005;125 
(2):169-76.

16) Dhong HJ, Kim HY, Chung YJ, Kim TW, Kim JH, Chung SK, et al. Computed tomographic assessment of chronic rhinosinusitis with asthma. Am J Rhinol 2006;20(5):450-2.

17) Kim HY, Dhong HJ, Chung SK, Chung YJ, Kim MG. Clinical characteristics of chronic rhinosinusitis with asthma. Auris Nasus Larynx 2006;33(4):403-8.

18) Rachelefsky GS, Katz RM, Siegel SC. Chronic sinus disease with associated reactive airway disease in children. Pediatrics 1984;73(4): 526-9.

19) Zavras AI, al-Bultan T, Jackson A, White G. Exposure to passive smoking and other predictors of reduced nasal volume in children 7 to 12 years old. J Clin Pediatr Dent 1997;21(4):295-303.

20) Hajnal BL, Braun-Fahrländer C, Grize L, Gassner M, Varonier HS, Vuille JC, et al. Effect of environmental tobacco smoke exposure on respiratory symptoms in children. SCARPOL Team. Swiss Study on Childhood Allergy and Respiratory Symptoms with Respect to Air Pollution, Climate and Pollen. Schweiz Med Wochenschr 1999; 129(19):723-30

21) Kim HY, Dhong HJ, Chung SK, Chung YJ, Min JY. Prognostic factors of pediatric endoscopic sinus surgery. Int J Pediatr Otorhinolaryngol 2005;69(11):1535-9.

22) Ramadan HH, Hinerman RA. Smoke exposure and outcome of endoscopic sinus surgery in children. Otolaryngol Head Neck Surg 2002;127(6):546-8.

23) Lieser JD, Derkay CS. Pediatric sinusitis: when do we operate? Curr Opin Otolaryngol Head Neck Surg 2005;13(1):60-6.

24) American Academy of Pediatrics. Subcommittee on Management of Sinusitis and Committee on Quality Improvement. Clinical practice guideline: management of sinusitis. Pediatrics 2001;108(3):798-808.

25) Suskind DL, Zeringue GP 3rd, Kluka EA, Udall J, Liu DC. Gastroesophageal reflux and pediatric otolaryngologic disease: the role of antireflux surgery. Arch Otolaryngol Head Neck Surg 2001; 127(5):511-4.

26) Bothwell MR, Parsons DS, Talbot A, Barbero GJ, Wilder B. Outcome of reflux therapy on pediatric chronic sinusitis. Otolaryngol Head Neck Surg 1999;121(3):255-62.

27) Phipps CD, Wood WE, Gibson WS, Cochran WJ. Gastroesophageal reflux contributing to chronic sinus disease in children: a prospective analysis. Arch Otolaryngol Head Neck Surg 2000;126(7):831-6.

28) Brook I. Bacteriology of acute and chronic ethmoid sinusitis. J Clin Microbiol 2005;43(7):3479-80.

29) Bernstein JM, Dryja D, Murphy TF. Molecular typing of paired bacterial isolates from the adenoid and lateral wall of the nose in children undergoing adenoidectomy: implications in acute rhinosinusitis. Otolaryngol Head Neck Surg 2001;125(6):593-7.

30) Elwany S, El-Dine AN, El-Medany A, Omran A, Mandour Z, ElSalam AA. Relationship between bacteriology of the adenoid core and middle meatus in children with sinusitis. J Laryngol Otol 2011; 125(3):279-81.

31) Eun YG, Park DC, Kim SG, Kim MG, Yeo SG. Immunoglobulins and transcription factors in adenoids of children with otitis media with effusion and chronic rhinosinusitis. Int J Pediatr Otorhinolaryngol 2009;73(10):1412-6.

32) Berçin AS, Ural A, Kutluhan A, Yurttaş V. Relationship between sinusitis and adenoid size in pediatric age group. Ann Otol Rhinol Laryngol 2007;116(7):550-3.

33) Triulzi F, Zirpoli S. Imaging techniques in the diagnosis and management of rhinosinusitis in children. Pediatr Allergy Immunol 2007;18 Suppl 18:46-9.

34) McAlister WH, Kronemer K. Imaging of sinusitis in children. Pediatr Infect Dis J 1999;18(11):1019-20.

35) Wald ER, Chiponis D, Ledesma-Medina J. Comparative effectiveness of amoxicillin and amoxicillin-clavulanate potassium in acute paranasal sinus infections in children: a double-blind, placebocontrolled trial. Pediatrics 1986;77(6):795-800.

36) Hsin CH, Tsao CH, Su MC, Chou MC, Liu CM. Comparison of maxillary sinus puncture with endoscopic middle meatal culture in pediatric rhinosinusitis. Am J Rhinol 2008;22(3):280-4.

37) Vogan JC, Bolger WE, Keyes AS. Endoscopically guided sinonasal cultures: a direct comparison with maxillary sinus aspirate cultures. Otolaryngol Head Neck Surg 2000;122(3):370-3.

38) Hsin CH, Su MC, Tsao CH, Chuang CY, Liu CM. Bacteriology and antimicrobial susceptibility of pediatric chronic rhinosinusitis: a 6-year result of maxillary sinus punctures. Am J Otolaryngol 2010; 31(3):145-9.

39) Otten FW, Grote JJ. Treatment of chronic maxillary sinusitis in children. Int J Pediatr Otorhinolaryngol 1988;15(3):269-78.

40) Otten HW, Antvelink JB, Ruyter de Wildt H, Rietema SJ, Siemelink RJ, Hordijk GJ. Is antibiotic treatment of chronic sinusitis effective in children? Clin Otolaryngol Allied Sci 1994;19(3):215-7.

41) Clement PA, Bluestone CD, Gordts F, Lusk RP, Otten FW, Goossens $\mathrm{H}$, et al. Management of rhinosinusitis in children. Int J Pediatr Otorhinolaryngol 1999;49 Suppl 1:S95-100.

42) Parsons DS. Chronic sinusitis: a medical or surgical disease? Otolaryngol Clin North Am 1996;29(1):1-9.

43) Rosenfeld RM. Pilot study of outcomes in pediatric rhinosinusitis. Arch Otolaryngol Head Neck Surg 1995;121(7):729-36.

44) Doern GV, Brueggemann AB, Pierce G, Holley HP Jr, Rauch A. Antibiotic resistance among clinical isolates of Haemophilus influenzae in the United States in 1994 and 1995 and detection of betalactamase-positive strains resistant to amoxicillin-clavulanate: results of a national multicenter surveillance study. Antimicrob Agents Chemother 1997;41(2):292-7.

45) Doern GV, Jones RN, Pfaller MA, Kugler K. Haemophilus influenzae and Moraxella catarrhalis from patients with community-acquired respiratory tract infections: antimicrobial susceptibility patterns from the SENTRY antimicrobial Surveillance Program (United States and Canada, 1997). Antimicrob Agents Chemother 1999;43(2):385-9.

46) Poole MD, Jacobs MR, Anon JB, Marchant CD, Hoberman A, Harrison CJ. Antimicrobial guidelines for the treatment of acute bacterial rhinosinusitis in immunocompetent children. Int J Pediatr Otorhinolaryngol 2002;63(1):1-13.

47) Centers for Disease Control and Prevention (CDC). Geographic variation in penicillin resistance in Streptococcus pneumoniae-selected sites, United States, 1997. MMWR Morb Mortal Wkly Rep 1999;48(30):656-61.

48) Dowell SF, Butler JC, Giebink GS, Jacobs MR, Jernigan D, Musher $\mathrm{DM}$, et al. Acute otitis media: management and surveillance in an era of pneumococcal resistance--a report from the Drug-resistant Streptococcus pneumoniae Therapeutic Working Group. Pediatr Infect Dis J 1999;18(1):1-9.

49) Wald ER, Applegate KE, Bordley C, Darrow DH, Glode MP, Marcy $\mathrm{SM}$, et al. Clinical practice guideline for the diagnosis and management of acute bacterial sinusitis in children aged 1 to 18 years. Pediatrics 2013;132(1):e262-80.

50) Bottenfield GW, Burch DJ, Hedrick JA, Schaten R, Rowinski CA, Davies JT. Safety and tolerability of a new formulation $(90 \mathrm{mg} / \mathrm{kg} /$ day divided every $12 \mathrm{~h}$ ) of amoxicillin/clavulanate (Augmentin) in the empiric treatment of pediatric acute otitis media caused by drugresistant Streptococcus pneumoniae. Pediatr Infect Dis J 1998;17 (10):963-8.

51) Don DM, Yellon RF, Casselbrant ML, Bluestone CD. Efficacy of a stepwise protocol that includes intravenous antibiotic therapy for the management of chronic sinusitis in children and adolescents. Arch Otolaryngol Head Neck Surg 2001;127(9):1093-8.

52) Adappa ND, Coticchia JM. Management of refractory chronic rhinosinusitis in children. Am J Otolaryngol 2006;27(6):384-9. 
53) Aukema AA, Mulder PG, Fokkens WJ. Treatment of nasal polyposis and chronic rhinosinusitis with fluticasone propionate nasal drops reduces need for sinus surgery. J Allergy Clin Immunol 2005;115(5): 1017-23.

54) Lund VJ, Black JH, Szabó LZ, Schrewelius C, Akerlund A. Efficacy and tolerability of budesonide aqueous nasal spray in chronic rhinosinusitis patients. Rhinology 2004;42(2):57-62.

55) Norès JM, Avan P, Bonfils P. Medical management of nasal polyposis: a study in a series of 152 consecutive patients. Rhinology 2003;41(2): 97-102.

56) Ozturk F, Bakirtas A, Ileri F, Turktas I. Efficacy and tolerability of systemic methylprednisolone in children and adolescents with chronic rhinosinusitis: a double-blind, placebo-controlled randomized trial. J Allergy Clin Immunol 2011;128(2):348-52.

57) Pham V, Sykes K, Wei J. Long-term outcome of once daily nasal irrigation for the treatment of pediatric chronic rhinosinusitis. Laryngoscope 2014;124(4):1000-7.

58) Hong SD, Kim JH, Kim HY, Jang MS, Dhong HJ, Chung SK. Compliance and efficacy of saline irrigation in pediatric chronic rhinosinusitis. Auris Nasus Larynx 2014;41(1):46-9.

59) Lieu JE, Piccirillo JF, Lusk RP. Prognostic staging system and therapeutic effectiveness for recurrent or chronic sinusitis in children. Otolaryngol Head Neck Surg 2003;129(3):222-32.

60) Sobol SE, Samadi DS, Kazahaya K, Tom LW. Trends in the management of pediatric chronic sinusitis: survey of the American Society of Pediatric Otolaryngology. Laryngoscope 2005;115(1):7880.

61) Talaat AM, Bahgat YS, el-Ghazzawy E, Elwany S. Nasopharyngeal bacterial flora before and after adenoidectomy. J Laryngol Otol 1989;103(4):372-4.

62) Lee D, Rosenfeld RM. Adenoid bacteriology and sinonasal symptoms in children. Otolaryngol Head Neck Surg 1997;116(3):301-7.

63) Lusk RP, Lazar RH, Muntz HR. The diagnosis and treatment of recurrent and chronic sinusitis in children. Pediatr Clin North Am 1989;36(6):1411-21.
64) Brietzke SE, Brigger MT. Adenoidectomy outcomes in pediatric rhinosinusitis: a meta-analysis. Int J Pediatr Otorhinolaryngol 2008; 72(10):1541-5

65) Ramadan HH, Tiu J. Failures of adenoidectomy for chronic rhinosinusitis in children: for whom and when do they fail? Laryngoscope 2007; 117(6):1080-3.

66) Ramadan HH, Cost JL. Outcome of adenoidectomy versus adenoidectomy with maxillary sinus wash for chronic rhinosinusitis in children. Laryngoscope 2008;118(5):871-3.

67) Jones J, Greenberg L, Groudine S, Guertin S, Hoffman R, Hollinger $\mathrm{I}$, et al. Clinical advisory: phenylephrine advisory panel report. Int $\mathrm{J}$ Pediatr Otorhinolaryngol 1998;45(1):97-9.

68) Ramadan HH. Surgical management of chronic sinusitis in children. Laryngoscope 2004;114(12):2103-9.

69) Hebert RL 2nd, Bent JP 3rd. Meta-analysis of outcomes of pediatric functional endoscopic sinus surgery. Laryngoscope 1998;108(6): 796-9.

70) Carpenter KM, Graham SM, Smith RJ. Facial skeletal growth after endoscopic sinus surgery in the piglet model. Am J Rhinol 1997;11 (3):211-7.

71) Mair EA, Bolger WE, Breisch EA. Sinus and facial growth after pediatric endoscopic sinus surgery. Arch Otolaryngol Head Neck Surg 1995;121(5):547-52.

72) Bothwell MR, Piccirillo JF, Lusk RP, Ridenour BD. Long-term outcome of facial growth after functional endoscopic sinus surgery. Otolaryngol Head Neck Surg 2002;126(6):628-34.

73) Senior B, Wirtschafter A, Mai C, Becker C, Belenky W. Quantitative impact of pediatric sinus surgery on facial growth. Laryngoscope 2000;110(11):1866-70.

74) Muntz H. Pediatric chronic rhinosinusitis. Curr Opin Otolaryngol Head Neck Surg 2004;12(6):505-8.

75) Ramadan HH, Terrell AM. Balloon catheter sinuplasty and adenoidectomy in children with chronic rhinosinusitis. Ann Otol Rhinol Laryngol 2010;119(9):578-82. 